\title{
PROFIL INDIKATOR PROGNOSIS BURUK PADA PASIEN MELASMA PERIODE JANUARI 2015-DESEMBER 2017 DI POLIKLINIK KULIT DAN KELAMIN RS DR. M. DJAMIL PADANG
}

\author{
Mimin Oktaviana, Satya Wydya Yenny, Yenny Raflis \\ Departemen Ilmu Kesehatan Kulit dan Kelamin \\ FK. Universitas Andalas/RSUP dr.M. Djamil, Padang
}

\begin{abstract}
ABSTRAK
Melasma merupakan kelainan kulit hipermelanosis dengan penyebab multifaktor. Terdapat beberapa indikator yang digunakan untuk memprediksi prognosis buruk dan potensi kegagalan pengobatan. Indikator tersebut adalah fenotip kulit III-VI, predisposisi genetik, pengobatan melasma jangka panjang $\geq 2$ tahun, riwayat intervensi dan prosedur sebelumnya, diobati oleh $\geq 2$ dokter, pengobatan sendiri dengan steroid jangka panjang, okronosis dan melasma tipe campuran. Dengan diketahuinya prognosis buruk pada pasien maka jenis pengobatan dan edukasi pada pasien dapat ditentukan. Penelitian ini bertujuan untuk mengetahui profil indikator prognosis buruk pada pasien melasma di Poliklinik Kulit dan Kelamin RS dr. M. Djamil Padang selama Januari 2015 hingga Desember 2017. Metode penelitian dilakukan secara retrospektif terhadap rekam medis pasien dengan mencatat jenis kelamin, jenis melasma dan indikator prognosis buruk. Hasil yang didapatkan dari 59 pasien melasma, 49,17\% berusia 24 - <44 tahun, dan 96,61\% adalah perempuan. Tipe melasma yang paling sering adalah tipe campuran (42,37\%). Indikator prognosis buruk yang terbanyak adalah fenotipe kulit III-VI (100\%), diikuti oleh melasma yang diobati oleh $\geq 2$ dokter $(76,27 \%)$ dan predisposisi genetik (62,71\%). Dapat disimpulkan fenotipe III-IV, diobati oleh $\geq 2$ dokter, dan predisposisi genetik adalah indikator untuk prognosis buruk terbesar pada melasma.
\end{abstract}

Kata kunci: indikator prognosis buruk, melasma

\section{PROFILE OF BAD PROGNOSIS INDICATORS IN PATIENT WITH MELASMA DURING JANUARY 2015 - DECEMBER 2017 IN DERMATOLOGY-VENEREOLOGY OUTPATIENT CLINIC OF DR. M. DJAMIL HOSPITAL PADANG}

\section{Korespondensi:}

J1. Perintis Kemerdekaan No. 94, Padang 25127

Telp : 0751-810256

Email:

mimin.oktaviana@gmail.com

\begin{abstract}
Melasma is a hypermelanotic skin disorder which etiology is multifactorial. Several indicators are used to predict lousy prognosis and potential treatment failure. The indicators are skin phenotype III-VI, genetic predisposition, long-term treatment of melasma $\geq 2$ years, previous intervention and procedural history, treated by $\geq 2$ doctors, self-treatment with long-term steroids, mixed type melasma and ochronosis. By knowing the lousy prognosis in patients, the type of treatment and education can be determined. This study aims to determine the profile of lousy prognosis indicators in melasma patients in Dermatology-Venereology Outpatient Clinic of dr. M. Djamil hospital Padang during January 2015-December 2017. This study was conducted retrospectively, consisting of age, sex, type of melasma, and bad prognosis indicators. The results of the 59 melasma patients, the majority were aged $24-<44$ years (49.17\%) and women (96.61\%). The most common type of melasma is the mixed type (42.37\%). The most prominent bad prognosis indicators are $100 \%$ phenotype III-VI, followed by melasma treated by $\geq 2$ doctors (76.27\%) and genetic predisposition (62.71\%). The conclusion of this study is phenotype III-IV, treated by $\geq 2$ doctors and genetic predisposition are the most significant indicators for the bad prognosis of melasma.
\end{abstract}

Key words: bad prognosis indicator, melasma 


\section{PENDAHULUAN}

Melasma (dari bahasa Yunani "melas", yang berarti 'hitam') adalah hipermelanosis yang sering terjadi pada kulit yang terpajan sinar matahari. Melasma merupakan salah satu gangguan pigmen yang paling umum ditemui oleh dokter spesialis kulit \& kelamin dan sering terjadi pada perempuan dengan kulit yang lebih gelap (Fitzpatrick skin type IV-VI). ${ }^{1}$ Melasma bersifat kronis dan berulang, menyebabkan gangguan secara kosmetik maupun tekanan psikologis. Kelainan ini sering tidak terdiagnosis dan tidak diterapi karena kurangnya terapi yang efektif serta adanya persepsi bahwa melasma hanyalah gangguan kosmetik. $^{2}$

Etiologi melasma bersifat multifaktorial. Terdapat beberapa kondisi yang menentukan hasil pengobatan melasma. Shankar dkk. menyatakan terdapat beberapa faktor dapat memprediksi kegagalan pengobatan atau prognosis buruk pada melasma yaitu fenotipe kulit III-VI, predisposisi genetik, pengobatan melasma jangka panjang $\geq 2$ tahun, prosedur intervensi (misal pengelupasan kimiawi, laser), diobati oleh $\geq 2$ dokter, pengobatan sendiri dengan steroid jangka panjang, okronosis dan melasma tipe campuran. ${ }^{1}$ Namun faktor prognostik ini tidak ada bukti ilmiah yang cukup mendukung. Tujuan penelitian ini adalah untuk mengetahui profil indikator prognosis buruk pada pasien melasma di Poliklinik Kulit dan Kelamin RS Dr. M. Djamil Padang selama Januari 2015-Desember 2017. Dengan demikian dapat digunakan untuk menentukan terapi dan materi edukasi kepada pasien.

\section{METODE}

Penelitian ini dilakukan secara retrospektif dengan cara mengumpulkan data dari rekam medis, yang terdiri atas usia, jenis kelamin, dan tipe melasma selama Januari 2015 hingga Desember 2017. Semua pasien dinilai oleh dokter spesialis kulit dan kelamin mengenai riwayat melasma secara rinci, riwayat keluarga dan riwayat pengobatan. Diagnosis berdasarkan pemeriksaan kulit dan pemeriksaan lampu Wood untuk menentukan tipe melasma.

\section{HASIL}

Pada penelitian ini didapatkan insidens melasma mulai Januari 2015 hingga Desember 2017 adalah 0,75\%. Dari 59 pasien yang diperiksa, 96,61\% adalah perempuan, mayoritas berada pada kelompok usia 24 sampai <44 tahun $(49,16 \%)$, dan tipe epidermal ditemukan pada 20 pasien $(33,90 \%)$, yang diperiksa dengan lampu Wood. Data karakteristik ini ditampilkan pada tabel 1 .
Tabel 1. Karakteristik pasien melasma di Poliklinik Kulit dan Kelamin RS dr. M. Djamil Padang periode Januari 2015-Desember 2017 (N=59 orang)

\begin{tabular}{|c|c|c|}
\hline & $\begin{array}{c}\text { Jumlah } \\
(\mathrm{n})\end{array}$ & $\begin{array}{c}\text { Persentase } \\
(\%)\end{array}$ \\
\hline \multicolumn{3}{|l|}{ Jenis Kelamin } \\
\hline - $\quad$ Laki-laki & 2 & 3,39 \\
\hline - $\quad$ Perempuan & 57 & 96,61 \\
\hline \multicolumn{3}{|l|}{ Umur (tahun) } \\
\hline $14-<24$ & 5 & 8,47 \\
\hline$-\quad 24-<44$ & 29 & 49,16 \\
\hline$-\quad 44-<64$ & 20 & 33,90 \\
\hline$-\quad \geq 64$ & 5 & 8,47 \\
\hline \multicolumn{3}{|l|}{ Tipe melasma } \\
\hline - Epidermis & 20 & 33,90 \\
\hline - Dermais & 14 & 23,73 \\
\hline - Campuran & 25 & 42,37 \\
\hline
\end{tabular}

Tabel 2. Profil indikator prognosis buruk melasma di Poliklinik Kulit dan Kelamin RS dr. M. Djamil Padang periode Januari 2015-Desember 2017. (N=59 Orang)

\begin{tabular}{lcc}
\hline \multicolumn{1}{c}{ Indikator } & $\begin{array}{c}\text { Total } \\
(\mathrm{n})\end{array}$ & $\begin{array}{c}\text { Persentase } \\
(\%)\end{array}$ \\
\hline Fenotip III-VI & 59 & 100 \\
Predisposisi genetik & 37 & 62,71 \\
Pengobatan melasma jangka panjang & 20 & 33,90 \\
$\geq 2$ tahun & & \\
Riwayat prosedur intervensi & 7 & 11,86 \\
Diobati oleh $\geq 2$ dokter & 45 & 76,27 \\
Pengobatan sendiri dengan steroid & 5 & 8,47 \\
jangka panjang & & \\
Okronosis & 0 & 0 \\
Melasma tipe campuran & 25 & 42,37 \\
\hline
\end{tabular}

Berdasarkan tabel 2, jumlah indikator tertinggi untuk prognosis buruk melasma adalah fenotipe kulit, Fitzpatrick phenotype III-VI pada 59 pasien (100\%), diikuti oleh pasien yang diobati oleh $\geq 2$ dokter sebanyak 45 pasien (76,27\%), dan predisposisi genetik 37 pasien $(62,71 \%)$. Selama Januari 2015 sampai Desember 2017, kami tidak menemukan pasien yang didiagnosis dengan okronosis, yang ditegakkan berdasarkan pemeriksaan fisik berupa bercak coklat keabuan atau hitam kebiruan serta pemeriksaan dermoskopi. 


\section{DISKUSI}

Penelitian ini menunjukkan melasma paling sering terjadi pada perempuan, yaitu sebanyak 96,61\%. Hasil penelitian ini sesuai dengan studi yang dilakukan oleh Haxel dkk. yang menyatakan perempuan lebih rentan menderita melasma. ${ }^{3}$ Dalam studi berbasis populasi tahun 2013 yang melibatkan 515 orang dewasa di Brazil, melasma diidentifikasi pada $34 \%$ perempuan dan pada 6\% laki-laki. Sebuah penelitian di India menemukan perbandingan prevalensi yang kurang bermakna antara perempuan dan laki-laki, yaitu 6:1, sedangkan di Brazil dan Singapura, prevalensi perempuan dan laki-laki masing-masing 39:1 dan 21:1. ${ }^{4}$

Di Poliklinik Kulit dan Kelamin RS dr. M. Djamil Padang selama Januari 2015 hingga Desember 2017, melasma paling sering terjadi pada kelompok usia 24 $<44$ tahun. Di Brazil, sebagian besar kasus perempuan (>50\%) dengan melasma berkembang antara dekade ketiga dan keempat kehidupan (20-35 tahun). Hasil penelitian ini sesuai dengan literatur yang menyatakan terdapat hubungan hormonal dalam patofisiologi melasma. Di Tunisia, 87\% perempuan berusia antara 20-40 tahun. Di India, Singapura, dan dalam studi global, rerata usia menderita melasma adalah 30, 34, dan 38 tahun. $^{4}$

Beberapa faktor dapat digunakan memprediksi potensi kegagalan pengobatan melasma. Moin dkk. menemukan hubungan yang bermakna secara statistik antara melasma dan etnis, phototype dan tingkat paritas. Namun, faktor prognostik ini belum cukup terbukti secara ilmiah. Indikator pertama adalah fenotipe III-VI, yaitu rambut gelap dan/atau kulit gelap. Melasma merupakan hasil perubahan pigmentasi kulit lokal karena dipengaruhi oleh fenotipe melanin, dan terutama mengenai tipe kulit menengah III-V menurut klasifikasi Fitzpatrick. ${ }^{4,5}$ Secara teori dikatakan bahwa individu dengan kulit tipe I gagal menghasilkan pigmentasi tambahan, dan individu dengan kulit tipe VI memproduksi melanin secara efisien. Dalam penelitian ini seluruh pasien melasma menunjukkan fenotipe kulit III-VI.

Indikator kedua adalah predisposisi genetik dan keluarga. Dalam penelitian ini, riwayat keluarga dengan melasma terdapat pada $62,71 \%$, sedikit lebih banyak dibandingkan dengan penelitian Moin dkk., yaitu 54,7\%. ${ }^{5}$ Sementara penelitian oleh Tamega dkk. menyatakan bahwa dari 302 penderita melasma, didapatkan riwayat melasma di keluarga adalah 56,3\%. ${ }^{6}$ Pada beberapa penelitian di Iran, Singapura, Spanyol dan AfrikaAmerika, adanya riwayat keluarga dengan melasma terdapat pada $10 \%$ hingga $70 \% .^{7}$

Dalam penatalaksanaan melasma, jenis dan tingkat deposit pigmen menentukan jenis perawatan yang diperlukan. Faktor utama yang perlu dipertimbangkan dalam menentukan prognosis dan pendekatan terapeutik adalah lokasi dan luasnya deposit pigmen abnormal.
Melasma tipe campuran mengenai pigmen epidermis dan dermis, dan biasanya refrakter terhadap perawatan konvensional dan tidak responsif terhadap monoterapi konvensional. ${ }^{8}$ Dalam penelitian ini, prevalensi pasien melasma tipe campuran terdapat sebanyak $42,37 \%$. Sebuah studi acak split-face oleh Wattanakrai dkk. mengobati 22 pasien melasma tipe campuran dengan jenis kulit Fitzpatrick III-V dan membandingkan pengobatan dengan laser Q-switched Nd: YAG rendah dikombinasi dengan hidrokuinon $2 \%$ topikal dibandingkan $2 \%$ hidrokuinon saja. Para peneliti menemukan bahwa sisi wajah yang dirawat dengan laser mencapai rerata peningkatan 92,5\% dibandingkan $19,7 \%$ pada sisi yang diobati dengan hidrokuinon. Penelitian tersebut menyatakan bahwa pasien fenotipe kulit III-V, dengan melasma tipe campuran, sebaiknya mempertimbangkan menggunakan terapi kombinasi. ${ }^{9,10}$

Indikator lain yang dapat memengaruhi prognosis buruk melasma adalah pengobatan melasma jangka panjang $\geq 2$ tahun. Pada penelitian ini pengobatan melasma jangka panjang terdapat pada $33,90 \%$, dan diobati oleh $\geq 2$ dokter adalah $76,27 \%$, riwayat prosedur intervensi sebanyak $11,86 \%$, terapi sendiri menggunakan steroid jangka panjang $8,47 \%$, sementara pada penelitian ini tidak ditemukan kasus okronosis. Okronosis eksogen umumnya muncul sebagai makula biru-hitam di daerah malar, pipi inferior dan leher. Hidrokuinon sejauh ini merupakan bahan yang paling umum dianggap sebagai penyebab okronosis. $^{8}$

Melalui indikator-indikator ini, diharapkan praktisi klinis dapat menentukan terapi yang lebih tepat, edukasi pasien untuk keberhasilan terapi dan prognosis pada masa mendatang, sehingga harapan berlebihan dan kekecewaan pasien dengan hasil terapi dapat dihindari. Masih dibutuhkan lebih banyak penelitian untuk mengevaluasi indikator ini.

\section{SIMPULAN}

Perempuan pada dekade ketiga dan keempat cenderung untuk menderita melasma. Di Poliklinik Kulit dan Kelamin RS dr. M. Djamil Padang, fenotipe kulit IIIVI, riwayat telah diobati oleh $\geq 2$ dokter dan predisposisi genetik merupakan indikator prognosis buruk melasma yang sering dijumpai, sehingga terapi dan materi edukasi untuk pasien dapat ditentukan.

\section{DAFTAR PUSTAKA}

1. Shankar K, Godse K, Aurangabadkar S, Lahiri K, Mysore V, Ganjoo A, dkk. Evidence based treatment for melasma: expert opinion and a review. Dermatol Ther. 2014;4:165-86.

2. Balkrishnan R, McMichael AJ, Camacho FT. Development and validation of a health related quality of life instrument for women with melasma. Br J Dermatol. 2003;149: 572-7. 
3. Hexsel D, Lacerda DA, Cavalcante AS, Filho M, Luiza C, Ayres LE, dkk. Epidemiology of melasma in Brazilian patients: a multicenter study. Int J Dermatol. 2013;53;440-4.

4. Handel AC, Miot LD, Miot HA. Melasma: a clinical and epidemiological review. An Bras Dermatol. 2014; 89(5):771-82.

5. Moin A, Jabery Z, Fallah N. Prevalence and awareness of melasma during pregnancy. Int J Dermatol. 2006;45:285-8.

6. Tamega Ade A, Miot LD, Bonfietti C, Gige TC, Marques ME, Miot HA. Clinical patterns and epidemiological characteristics of facial melasma in Brazilian women. J Eur Acad Dermatol Venereol. 2013;27:151-156

7. Sarkar R, Ailawadi P, Garg S. Melasma in men: a review of clinical, etiological and management issues. JCAD. 2018;11:53-59.
8. Park KY, Kim DH, Kim HK, Seo SJ, Kong CK. A randomized, observer blinded comparison of combined $1064 \mathrm{~nm}$ Q switched neodymium doped yttrium aluminium garnet laser plus 30\% glycolic acid peel vs. laser monotherapy to treat melasma. Clin Exp Dermatol. 2011;36:864-70.

9. Trivedi MK, Yang FC, Cho BK. A review of laser and light therapy in melasma. Int J Womens Dermatol.2017; 1-10.

10. Wattanakrai P, Mornchan R, Eimpunth S. Low-fluence qswitched neodymium-doped yttrium aluminum garnet $(1,064 \mathrm{~nm})$ laser for the treatment of facial melasma in Asians. Dermatol Surg. 2010;36:76-87. 